\title{
Is hypoalbuminemia a predictor marker of mortality?
}

\author{
DOI: https:// doi.org/10.22435/hsji.v11i2.3072
}

\author{
Siti Maemun ${ }^{1,2}$, Nina Mariana ${ }^{1}$, Surya Otto Wijaya ${ }^{1}$, Dina Oktavia ${ }^{1}$, Vivi Lisdawati ${ }^{1}$, Rita Rogayah ${ }^{1}$ \\ ${ }^{1}$ Prof. Dr. Sulianti Saroso Infectious Disease Hospital, Jakarta \\ ${ }^{2}$ Faculty of Public Health, University of Respati Indonesia Jakarta, Indonesia
}

Corresponding author: Nina Mariana

Email: mynayla09@yahoo.com

Received: March 9, 2020; Revised: April 6, 2020; Accepted: October 19, 2020

\begin{abstract}
Abstrak
Latar belakang: Hipoalbuminemia pada pasien rawat inap berkaitan dengan prognosis buruk pasien. Penelitian ini, mengidentifikasi bahwa hipoalbuminemia berat pada awal pasien masuk rawat inap sebagai prediktor andalan penanda laboratorium dalam mortalitas.

Metode: Sebuah studi cross sectional pada pasien dewasa dengan hipoalbuminemia (kadar albumin $<3,5 \mathrm{~g}$ /dL) pada pasien rawat inap (usia > 18 tahun) pada periode Januari 2013 - Maret 2018. Kami mengevaluasi penanda prediktor kematian. Multivariat dengan regresi logistik diterapkan dalam penelitian ini.

Hasil: Dari 747 hipoalbuminemia pada pasien rawat inap dengan rata-rata kadar albumin pada awal adalah 2,0 $\pm 0,6 \mathrm{~g} / \mathrm{dL}$. Sebagian besarpasien (83,4\%) memiliki kadar albumin $\leq 2,5 \mathrm{~g} / \mathrm{dL}$ (hipoalbuminemia berat), 16,6 persen memiliki $>2,5 \mathrm{~g} / \mathrm{dL}$ (hipoalbuminemia ringan-sedang). Kondisi yang mendasari pasien adalah infeksi HIV / AIDS (26,9\%) dan sepsis (26,6\%). Proporsi multiple komorbiditas pada kelompok hipoalbuminemia berat adalah 55,1 persen Pada kelompok hipoalbuminemia berat terutama untuk kadar albumin 2,01 - 2,5 g / dL, angka mortalitas adalah 28,3 persen. Berdasarkan model regresi logistik akhir, faktor risiko kematian meliputi kadar albumin pada awal dan lama rawat pasien. Mortalitas lebih tinggi pada pasien dengan hipoalbuminemia berat (rasio odds yang disesuaikan 2,91, 95\% CI 1,884,50) dibandingkan pasien dengan hipoalbuminemia ringan-sedang.
\end{abstract}

Kesimpulan: Hipoalbuminemia berat pada awal pasien rawat inap sebagai prediktor penanda kematian di rumah sakit. (Health Science Journal of Indonesia 2020;11(2):121-5)

Kata kunci: hipoalbuminemia, pasien rawat inap, mortalitas

\begin{abstract}
Background: Hypoalbuminemia in hospitalized patients has been associated with poor prognosis. In this study, we attempted to identify that severe hypoalbuminemia at baseline in hospitalized patients is a reliable predictor of laboratory marker for mortality.

Methods: A cross sectional study on adults of hypoalbuminemia (albumin level $<3.5 \mathrm{~g} / \mathrm{dL}$ ) in hospitalized patients (aged $>18$ years old) in period January 2013 - March 2018. We evaluated the predictor marker of mortality. Multivariate with the logistic regression was applied in this study.

Result: Of the 747 hypoalbuminemia in hospitalized patients with the mean albumin level at baseline was $2.0 \pm 0.6 \mathrm{~g} / \mathrm{dL}$. Most patients $(83.4 \%$ ) had less than or equal to $2.5 \mathrm{~g} / \mathrm{dL}$ albumin level (severe hypoalbuminemia), 16.6 percent had over $2.5 \mathrm{~g} / \mathrm{dL}$ (mild-moderate hypoalbuminemia). The underlying condition of patients was HIV/AIDS infection (26.9\%) and sepsis $(26.6 \%)$. The proportion of multiple comorbidities in the severe hypoalbuminemia group was 55.1percent. In the severe hypoalbuminemia group especially for $2.01-2.5 \mathrm{~g} / \mathrm{dL}$ albumin level, the mortality rate was 28.3 percent. Based on the final logistic regression model, known risk factors of mortality include albumin level at baseline and length of stay. Mortality was higher among patients with severe hypoalbuminemia (adjusted odds ratio 2.91, $95 \%$ CI 1.88-4.50) than patients with mild-moderate hypoalbuminemia.
\end{abstract}

Conclusion: Severe hypoalbuminemia at baseline in the hospitalized patients was a predictor laboratory marker of hospital mortality. (Health Science Journal of Indonesia 2020;11(2):121-5)

Keywords: hypoalbuminemia, hospitalized patients, mortality 
Hypoalbuminemia is common in hospitalized patients. Hypoalbuminemia is the result of the effects of acute organ dysfunction, inflammatory disorders, and also inadequate protein and caloric intake in patients with chronic disease. ${ }^{1}$ As we know that albumin has some important roles in the body, including maintaining oncotic pressure and binding a variety of molecules. ${ }^{2}$

The association between hypoalbuminemia and poor prognosis is well progressively increased morbidity and mortality. ${ }^{3}$ The risk of prolonged hospital stay increased by 16 percent and the risk of increased death by 39 percent for each $2.5 \mathrm{mg} / \mathrm{L}$ serum albumin drop. ${ }^{2}$

Vincent et al performed hypoalbuminemia as an independent predictor of poor outcomes in patients with acute illness. ${ }^{4}$ Severe hypoalbuminemia represents a potential predictor of adverse in hospitalized patients. To our knowledge, the clinical relevance of hypoalbuminemia has not yet been fully evaluated in this clinical setting. The aim of the present study was to evaluate the predictor marker of mortality.

\section{METHODS}

A cross sectional study on adults of hypoalbuminemia (albumin level $<3.5 \mathrm{~g} / \mathrm{dL}$ ) in hospitalized patients of Sulianti Saroso Infectious Diseases Hospital (aged $>18$ years old) in period January 2013 until March 2018. We had a total sample of 747 patients that completed the variable of data. Data collection from hospital management information system and medical record. Descriptive analysis for baseline characteristic patients based on albumin levels and bivariate analysis to get significance of variable. The variable as predictor marker were age $>65$ years old, HIV infection, sepsis condition, Length of Stay (LoS) more 8 days, ICU ward, severe hypoalbuminemia. We evaluated the predictor marker of mortality. Multivariate analysis included independent variable with $p$-value less than 0.25 and odss ratio (OR) for the logistic regression were applied in this study. Data was analyzed using SPSS version 21 . The study protocol was approved by the Ethics Committee at Sulianti Saroso Infectious Diseases Hospital, number: 17/XXXVIII.10/V/2018.

\section{RESULTS}

Of the 747 hypoalbuminemia in hospitalized patients with the mean albumin level at baseline was $2.0 \pm 0.6$ $\mathrm{g} / \mathrm{dL}$. Most patients $(83.4 \%$ ) had less than or equal to $2.5 \mathrm{~g} / \mathrm{dL}$ albumin level (severe hypoalbuminemia); 16.6 percent had over $2.5 \mathrm{~g} / \mathrm{dL}$ to $3.5 \mathrm{~g} / \mathrm{dL}$ (mild - moderate hypoalbuminemia). The underlying condition of severe hypoalbuminemia patients was HIV/AIDS infection $(29.9 \%)$ and sepsis $(24.6 \%)$.

Table 1 shows that patients with severe hypoalbuminemia were less than or equal 65 years old and more likely to be male, hospitalized for more than 8 days in a non ICU ward and they also had multiple comorbidities $(p=0.000)$ such as diabetes mellitus, tuberculosis, heart failure, renal disease.

Table 1. Baseline characteristic of the study patients according to the albumin levels

\begin{tabular}{|c|c|c|c|}
\hline \multirow{2}{*}{ Variabels } & \multicolumn{2}{|c|}{ Albumin level at baseline } & \multirow[b]{2}{*}{$\mathrm{p}$} \\
\hline & $\begin{array}{c}\text { Severe Hypoalbuminemia } \\
\text { n (\%) }\end{array}$ & $\begin{array}{c}\text { Mild-moderate hypoalbuminemia } \\
\mathrm{n}(\%)\end{array}$ & \\
\hline \multicolumn{4}{|l|}{ Age in years } \\
\hline$>65$ & $115(18.5 \%)$ & $36(29.0 \%)$ & \multirow[t]{2}{*}{0.011} \\
\hline $18-65$ & $508(81.5 \%)$ & $88(71.0 \%)$ & \\
\hline \multicolumn{4}{|l|}{ Sex } \\
\hline Female & $260(41.7 \%)$ & $51(41.1 \%)$ & \multirow[t]{2}{*}{0.980} \\
\hline Male & $363(58.3 \%)$ & $73(58.9 \%)$ & \\
\hline \multicolumn{4}{|l|}{ HIV Infection } \\
\hline Yes & $186(29.9 \%)$ & $15(12.1 \%)$ & \multirow[t]{2}{*}{0.000} \\
\hline No & $437(70.1 \%)$ & $109(87.9 \%)$ & \\
\hline \multicolumn{4}{|l|}{ Sepsis } \\
\hline Yes & $153(24.6 \%)$ & $46(37.1 \%)$ & \multirow[t]{2}{*}{0.006} \\
\hline No & $470(75.4 \%)$ & $78(62.9 \%)$ & \\
\hline \multicolumn{4}{|l|}{ Length of Stay in days } \\
\hline$\geq 8$ & $496(79.6 \%)$ & $107(86.3 \%)$ & 0.478 \\
\hline $4-7$ & $103(16.5 \%)$ & $15(12.1 \%)$ & 0.201 \\
\hline $1-3$ & $24(3.9 \%)$ & $2(1.6 \%)$ & Ref \\
\hline \multicolumn{4}{|l|}{ Room } \\
\hline ICU & $91(14.6 \%)$ & $42(33.9 \%)$ & \multirow[t]{2}{*}{0.000} \\
\hline Non ICU & $532(85.4 \%)$ & $82(66.1 \%)$ & \\
\hline \multicolumn{4}{|c|}{ Amount of Comorbidities } \\
\hline$\geq 3$ & $343(55.1 \%)$ & $94(75.8 \%)$ & \multirow[t]{2}{*}{0.000} \\
\hline$<3$ & $280(44.9 \%)$ & $30(24.2 \%)$ & \\
\hline
\end{tabular}


Overall,251(33.6\%)patientsdiedduringhospitalization. Mortality was higher with severe hypoalbuminemia $(72.5 \%)$ than mild-moderate hypoalbuminemia (27.5 $\%)$. In severe hypoalbuminemia group especially for $2.01-2.5 \mathrm{~g} / \mathrm{dL}$ albumin level mortality rate was 28.3 percent followed by 1.51-2.0 g/dL (27\%) and 1.01$1.5 \mathrm{~g} / \mathrm{dL}(14 \%)$. In-hospital mortality rate for each albumin level are shown in Fig. 1. The patients with severe hypoalbuminemia group died within $16 \pm 12$ days (mean $\pm \mathrm{SD})$.

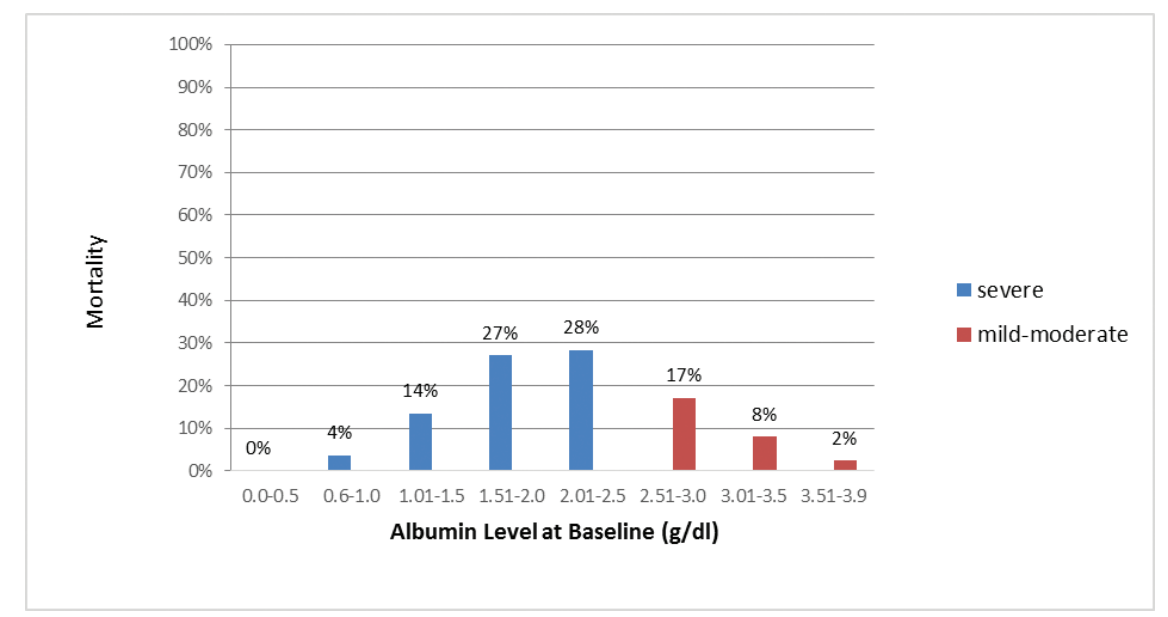

Figure 1. In hospital mortality rate by albumin level

Tabel 2. The bivariable analysis and multivariable logistic regression to validate factors associated with the mortality.

\begin{tabular}{lcccc}
\hline \multicolumn{1}{c}{ Parameters } & \multicolumn{1}{c}{$\begin{array}{c}\text { Bivariable Analysis } \\
\text { Odds Ratio (95\% CI) }\end{array}$} & p & \multicolumn{2}{c}{$\begin{array}{c}\text { Multivariable Analysis } \\
\text { Odds Ratio (95\% CI) }\end{array}$} \\
\hline pge $>$ 65 years old & $1.35(0.98-1.80)$ & 0.084 & $0.67(0.44-1.03)$ & 0.071 \\
Hypoalbuminemia with HIV infections & $1.33(0.93-1.96)$ & 0.118 & $0.48(0.33-0.72)$ & 0.000 \\
Hypoalbuminemia with sepsis & $3.46(2.47-4.86)$ & 0.000 & $0.41(0.28-0.60)$ & 0.000 \\
Length of Stay more 8 days & $1.83(0.78-4.29)$ & 0.168 & $3.20(1.39-7.41)$ & 0.006 \\
In ICU ward & $4.98(3.34-7.41)$ & 0.000 & $0.31(0.20-0.48)$ & 0.000 \\
Severe hypoalbuminemia & $0.33(0.22-0.49)$ & 0.000 & $2.91(1.88-4.50)$ & 0.000 \\
\hline
\end{tabular}

In Table 2. Mortality is dependently related to the following markers, which are ranked in order from the higgest odds ratio (OR) as length of stay more 8 days (OR [95\%CI] : 3.20 [1.39-7.41], $\mathrm{p}=0.006)$ and severe hypoalbuminemia (OR[95\% CI] : 2.91[1.88-4.50], $\mathrm{p}=0.000)$. In contrast the risk of hypoalbuminemia patients with HIV infections (OR[95\%CI]: 0.48[0.33$0.72], \mathrm{p}=0.000$ ), and hypoalbuminemia patients with sepsis (OR [95\%CI]: 0.41 [0.28-0.60], p =0.000), also patients in ICU ward (OR[95\%CI]: 0.31 [0.20-0.48], $\mathrm{p}=0.000)$ was lower.

\section{DISCUSSION}

Our data showed that the mortality rate of the severe hypoalbuminemia group at baseline was higher than the mild-moderate hypoalbuminemia. The proportion of patients with $1.01-1.5 \mathrm{~g} / \mathrm{dL}$ albumin level was lower (14\%) than $2.01-2.5 \mathrm{~g} / \mathrm{dL}$ albumin level group (28.3\%). Because the majority of patients with $\leq 1.5 \mathrm{~g} / \mathrm{dL}$ albumin level were in non
ICU ward and less comorbidities rather than patients with $2.01-2.5 \mathrm{~g} / \mathrm{dL}$ albumin level. However, this result assumed that low albumin level and critical ill condition at baseline are probably comparable in predicting mortality. ${ }^{5}$ Our hospital mortality rate data was in line with the previous study : around $34 \%$ in severe hypoalbuminemia patients on admission. ${ }^{6}$

Our data showed that low albumin level at baseline in hospitalized patients had a significant association with an increased risk of morbidity and mortality. ${ }^{7}$ On multivariable analysis for mortality, severe hypoalbuminemia $(\leq 2.5 \mathrm{~g} / \mathrm{dL}$ albumin level) was a predictive laboratory marker of in-hospital mortality. Similar to the previous study in spesific groups of patients have shown that initial albumin levels were independently associated with in-hospital mortality among adult patients hospitalized with aspiration pneumonia. ${ }^{8}$ Another study, of the 707 Necrotizing fasciitis patients with hypoalbuminemi in the emergency department $(3.1 \pm 0.9 \mathrm{~g} / \mathrm{dL})$. Showed that albumin level was significantly lower in the non 
survivor group ( death occurring in the hospital after admission) than in the survivor group $(2.8 \pm 0.7 \mathrm{~d} / \mathrm{dL}$ vs $3.5 \pm 0.8 \mathrm{~g} / \mathrm{dL}) .{ }^{5}$ Albumin level was significantly predicted with in-hospital mortality (OR $[95 \% \mathrm{CI}]$ : $0.92[0.88-0.96], \mathrm{p}<0.001){ }^{5}$

In fact, in this study, the risk of hypoalbuminemia in patients with HIV infections, sepsis, and patients in ICU ward was lower. However, the underlying condition of patients was HIV/AIDS infection $(26.9 \%)$ and sepsis $(26.6 \%)$, also the most proportion of patients had multiple comorbidities. Hypoalbuminemia requires careful management of their condition. HIV infection can be caused of hypoalbuminemia that produces chronic inflammation and related to chronic malnutrition..$^{3,5,9}$

The cause of hypoalbuminemia in sepsis patients are often multifactorial, such as decreased albumin synthesis, increased albumin loss, redistribution of albumin to locations outside the intravascular space, and dilution of albumin within the intravascular space. ${ }^{9}$ In addition, some drugs, including antibiotics, can bind with plasma protein and form proteindrug complexes. ${ }^{9}$ Binding to plasma proteins plays a major role in drug treatment. ${ }^{5}$ However, severe hypoalbuminemia may result in potentially lifethreatening consequences. ${ }^{9}$

The most important concept in treating hypoalbuminemia patients is to address the underlying problem. ${ }^{7,8}$ The appropriate treatment of hipoalbuminemia is needed based on the reason for the low albumin level. In addition, it is uncertain whether correcting hypoalbuminemia with continuously albumin infusion administration is more beneficial or not. However, although the role of albumin infusion therapy for the correction of hypoalbuminemia is still controversial related to the high cost of health facilities, albumin infusion administration is one of an effort to reduce the poor prognosis of patients if the therapy is correctly prescribed and rationally used. ${ }^{10}$

Additionally, the initial albumin level at baseline is important to check on the health care system. It can be a laboratory marker for predicting in -hospital mortality. ${ }^{11,12,13}$ Our study has several limitations. We do not have any data on the severity degree of sepsis patients such as SOFA score that can be the prognostic performance of an albumin value. ${ }^{14}$ However, the prognostic accuracy of the combination of albumin level and SOFA score was not significantly better than the use of SOFA score alone $(p=0,274) .{ }^{5}$ Other than that, we do not have information regarding the nutritional status of patients, other than body mass index, which may be of relevance in this case. ${ }^{15}$

In conclusion, severe hypoalbuminemia at baseline in the hospitalized patients was a predictor laboratory marker of hospital mortality. However, although the role of albumin infusion therapy for the correction of hypoalbuminemia is still controversial, the administration of albumin infusion is one of an effort to reduce the poor prognosis of patients if the therapy is correctly prescribed and used rationally in relation to the underlying problem.

\section{Acknowledgement}

We would like to acknowledge director and staff of Sulianti Saroso Hospital. The study was conducted by the hospital study team in 2018 .

\section{Conflict of Interest}

The authors declare that there is no conflict of interest.

\section{REFERENCES}

1. Char WC, Yih YC, Chin LL, Solomon CC, Yi Jen C, Ming SL. Severe hypoalbuminemia is a strong independent risk factor for acute respiratory failure in COPD : a nationwide cohort study. International Journal of COPD, 2015; 10 : 1147-54.

2. Haroldo F, Andre M. Albumin in critically ill patients: controversies and recommendations. Rev Bras Ter Intensive, 2011; 23; 87-95.

3. Christoper V, Eleni T, Andrew D, Banwari A. Human albumin solution for patients with cirrhosis and acute on chronic liver failure : beyond simple volume expansion. World J Hepatol, 2016; 8: 345-54.

4. Vincent JL, Dubois MJ, Navickis RJ, Wilkes MM. Hypoalbuminemia in acute illness: is there a rationale for intervention? a meta-analysis of cohort studies and controlled trials. Ann Surg, 2003: 237(3):319-34.

5. Chia PC, Wen CF, Cheng TH. Diagnostic performance of initial serum albuminemia level for prediction in hospital mortality among necrotizing fasciitis patients. J.Clin Med, 2018;7:435.

6. Amit A, Hiba MI, Alaa A, Ilan S. Low albumin levels are associated with mortality risk in hospitalized patients. The American journal of medicine, 2017; 130: 1465.e11-1465.e19.

7. Ruben Peralta. Hypoalbuminemia [Internet]. https://emedicine.medscape.com/article/166724overview\#a4. [cited 2018 Dec 3].

8. Hyosun K, Sion J, Jaebaek L, Young J, Taeoh J, Jaecol Y, et al. Diagnostic performance of initial serum albumin lever for predicting in-hospital mortality among aspiration pneumonia patients. The 
American Journal of emergency medicine, 2017: 36:5-11.

9. Juliere L, Marie E, Leah A. Albumin in health and disease : cause and treatment of hypoalbuminemia. International medicine compendium, 2019:12;1-5.

10. Farzaneh F, Shariar M. Investigating the use of human albumi in a non teaching hospital in Iran. Irian Journal of pharmaceutical research, 2017; 16: 817-22.

11. Levitt DG, Levitt MD. Human serum albumin homeostasis: a new look at the roles of synthesis, catabolism, renal and gastrointestinal excretion, and the clinical value of serum albumin measurements. Int J Gen Med. 2016;9:229-55. [PMC free article] [PubMed].

12. Cabrerizo S, Cuadras D, Gomez-Busto F, ArtazaArtabe I, Marín-Ciancas F, Malafarina V. Serum albumin and health in older people: Review and meta analysis. Maturitas. 2015 May;81(1):1727. [PubMed]

13. Brock F, Bettinelli LA, Dobner T, Stobbe JC, Pomatti G, Telles CT. Prevalence of hypoalbuminemia and nutritional issues in hospitalized elders. Rev Lat Am Enfermagem. 2016 Aug 08;24:e2736. [PMC free article] [PubMed]

14. Anibal B, Alessandra F, Mayra G, Edson A, Lorena A, Roosevelt S, et al. The use of APACHE II, SOFA, SAPS 3, C-reactive protein/albumin ratio, and lactate to predict mortality of surgical critically ill patients : a retrospective cohort study. Medicine. 2019; 98:26.

15. Lauriane F, Julien B, Marc M, Kossar H, Christine R, Luciane $\mathrm{S}$, et al. Serum albumin or body mass index : which prognostic factor for survival in patients with acute myeloblastic leukaemia ?. Hematol Oncol. 2019; 37:80-4. 